\title{
唾液アミラ一ゼ活性を用いた月経周期に伴う女性のストレス評価 \\ Evaluation of Stress on Menstrual Cycle Using Salivary Amylase Activity
}

\author{
中川朝美 (正会員)*, 佐々木 誠 (正会員)*, 山口 昌樹 (正会員)*
}

Asami Nakagawa*, Makoto Sasaki*, Masaki Yamaguchi*

\begin{abstract}
Salivary biomarkers provide valuable information about various health conditions. The purpose of this study is to evaluate the possibility of salivary biomarkers which can be collected noninvasively as the indexes of menstrual cycle. Twenty-eight healthy female subjects were enrolled ( $33.4 \pm 4.8 \mathrm{yr}$, mean $\pm \mathrm{SD}$ ). Menstrual distress questionnaire (MDQ) was used as an index of the menstrual symptoms in order to compare salivary stress biomarker. The salivary a-amylase activity (SAA) was used as an index of the sympathetic nervous activity. The salivary progesterone was used as an index of the female sex hormone. The results showed a significant correlation between the salivary progesterone concentration during the postmenstrual period and the MDQ scores of the premenstrual and menstrual periods. This correlation followed well with the previous study. We also compared the subtract SAA of postmenstrual period from premenstrual and menstrual periods $(\triangle \mathrm{SAA}$ ) with the MDQ scores. It was found that a significant correlation between the $\triangle \mathrm{SAA}$ for the night during the premenstrual period and the MDQ scores of premenstrual, menstrual and postmenstrual periods. These results suggested a possibility that the salivary amylase can be used as an index of the menstrual symptoms.
\end{abstract}

\section{Key Words}

Saliva, Amylase, Progesterone, Menstrual Distress Questionnaire, Menstrual Cycle

\section{1. はじめに}

月経によって, 気分や行動が阻害されることは, よく知られ ている. 月経と気分に関する科学的なアプローチは, Frank らによる月経前 7 - 10 日から始まる前段緊張の報告から始 まるとされる 1). Greene と Dalton は前生理症状（前症候 群）の多様性を指摘し 2), Dalton は生理の影響を受けない 体細胞はほとんどないことを示唆している ${ }^{3)}$.

2012 年 4 月 9 日受理

2012 年 7 月 12 日最終原稿受理

*岩手大学大学院工学研究科

岩手県盛岡市上田 4-3-5

*Graduate School of Engineering, Iwate University 4-3-5 Ueda, Morioka, Iwate, Japan
ヒトは周期的排卵動物であり, おおよそ 28 日周期で繰り返 される月経周期は月経期, 卵胞期, 排卵期, 黄体期の 4 つ に分けられる. 月経は, 下垂体でつくられる黄体形成ホルモ ンと卵胞刺激ホルモン, 卵巣でつくられる女性ホルモンのエ ストロゲンとプロゲステロンによって調整される. エストロゲンは 排卵ホルモンと呼ばれるように, 排卵前に濃度がピークを示 す.プロゲステロンは, 子宮を妊娠の準備をするように変化さ せて月経周期を決め, 黄体期に高值を示す. 女性ホルモン の急激な変化に付随して, 月経前症候群や月経困難症など の身体的, 精神的不調・変調（月経随伴症状）を自覚する 女性は多い.

本研究では，月経に伴う心身ストレスに関して，唾液から非 侵襲的に分析可能な交感神経指標による定量評価の有効 性を検証することを目的としている. 月経周期に伴う心身両 面にわたる愁訴（月経随伴症状）の定量化には, Moos が 
作成した MDQ (menstrual distress questionnaire) ${ }^{4), 5)}$ という質問紙の日本語版 6)を用い, 唾液バイオマーカーの值 と比較した. 交感神経活性の指標には, 唾液に含まれるアミ ラーゼ（唾液アミラーゼ）の活性を用いた. 性周期の同定に は, 唾液から分析可能な女性ホルモンとしてプロゲステロン （唾液プロゲステロン）の濃度を用いた. 20 代から 40 代まで の健常な成人女性 28 名を対象として, 月経随伴症状と唾液 バイオマーカーの経時変化との関連性を比較検討した.

\section{1 被検者}

\section{2. 対象と方法}

被検者は, 月経周期が正常な 20 代から 40 代までの健常 成人女性 28 名 $(33.4 \pm 4.8$ 歳, mean $\pm \mathrm{SD})$ とした. 本検 査のプロトコルは, 岩手大学倫理委員会の承認を受けた. 被 検者には, 検査の趣旨を口頭と書面の双方で十分に説明し, 書面で同意を得た.

\section{2 検査プロトコル}

本検査は, 被検者の自宅や外出先を含む日常生活にお いて実施した。検查期間は，被検者の自己申告をもとに設定 した月経開始予定日 7 日前から, 月経終了後 7 日間までの 約 3 週間とした. 寸なわち, 月経前は月経開始予定日から月 経開始までの 7 日間, 月経中は月経開始から終了までの 5 - 7 日間（月経期は被検者で異なる）, 月経後は月経終了 の 7 日間と定義した.

月経終了 7 日後には, 月経随伴症状に関する主観評価ア ンケートを実施した.

\section{3 唾液アミラ一ゼの分析}

唾液アミラーゼ活性（salivary amylase activity; SAA） の分析には, 携帯式の唾液アミラーゼモニター (ニプロ(株) を用いた 7),8). 被検者は, 唾液採取紙を口腔に挿入し, 舌下 部から $30 \mu \mathrm{l}$ 程度の極微量な唾液を採取した後, 唾液アミ ラーゼモニターに表示される手順に従って, 唾液アミラーゼ 活性を即時分析した。

唾液アミラーゼの分析に使用する唾液は, 1 日 3 回（朝, 昼, 夜) 採取した. 加えて, 心身ストレスを強く感じることが多 い月経中の生理用品の交換前後でも, 唾液採取と唾液アミ ラーゼ活性の分析を行った.

\section{4 唾液プロゲステロン濃度の分析}

唾液プロゲステロン濃度の分析に使用する唾液は, 3 日に 1 回の間隔で夜のみ採取した. 唾液プロゲステロン濃度の分 析には, ELISA キット (Salivaly Progesterone Enzyme Kit, 1-1502, Salimetrics LLC, USA) と蛍光プレートリー ダー（測定波長 $450 \mathrm{~nm}$, ARVO MX, PerkinElmer Inc., USA）を用いた。唾液採取は, 採取前 12 時間以内に飲酒し ていない夜間に, 被検者自身が舌下に歯科用綿（Ø8×12 $\mathrm{mm}) 1$ 個を $1-2$ 分入れた後, 蓋付の滅菌済みサンプル チューブに吐き出し蓋をする方法を取った.

\section{5 主観評価}

主観評価には, MDQ の日本語版を用いた. MDQ は,
「痛み」,「集中力の低下」,「行動の変化」,「自律神経失調」, 「水分貯留」, 「否定的情緒」,「気分の高揚」,「コントロール」 の 8 因子に関連した合計 47 項目について, 「症状なし $(0$ 点) 」, 「弱い (1 点)」,「中程度 (2 点)」,「強い (3 点)」の 4 段階評価を行うものである. 本研究では, 月経周期を思い起 こして回答する $\mathrm{MDQ} の \mathrm{~A}$ タイプを採用し, 月経前, 月経中, 月経後に対する主観評価を月経終了 7 日後に実施した.

\section{6 統計処理}

群間の比較には，一元配置分散分析および Wilcoxonの 符号順位和検定を用いた（SPSS Statistics 20.0, 日本 IBM, Tokyo, Japan).いずれも, $P<0.05$ を有意差ありと 判定した. 特に断りのない場合, データは mean $\pm \mathrm{SD}$ で示 した. なお，唾液アミラーゼ活性が $150 \mathrm{kU} / \mathrm{l}$ 以上,もしくは $5 \mathrm{kU} / 1$ 未満のデータは, 唾液アミラーゼモニターの測定範 囲から外れるため, 分析から除外した。

\section{3. 結果}

\section{1 唾液アミラーゼ活性}

全被検者の唾液アミラーゼ活性は, $10.7-108.5 \mathrm{kU} / \mathrm{l}$ の範囲に分布した．月経前，月経中，月経後の朝の唾液アミ ラーゼ活性は, それぞれ $35.8 \pm 17.7,34.1 \pm 18.9,32.8$ $\pm 16.5 \mathrm{kU} / \mathrm{l}$, 昼の活性は $45.5 \pm 20.1,43.4 \pm 20.4$, $44.1 \pm 21.9 \mathrm{kU} / 1$, 夜の活性は $45.4 \pm 22.9,45.0 \pm 24.2$, $43.9 \pm 21.9 \mathrm{kU} / 1$ であった. 独立変数を月経周期, 従属変 数を SAA として二元配置分散分析を行った結果, 月経前, 月経中, 月経後の SAA には, 統計的な有意差は認められな かった $(F[2,81]=0.21, P=0.81$, Fig.1). また, 月経前, 月経中, 月経後の各 $\mathrm{SAA}$ に対し, 朝, 昼, 夜ごとにそれぞれ Wilcoxon の符号順位和検定を行った結果，いかなる場合に おいても統計的な有意差は認められなかった（いずれも $d f$ =27, $P>0.09$, n.s.).

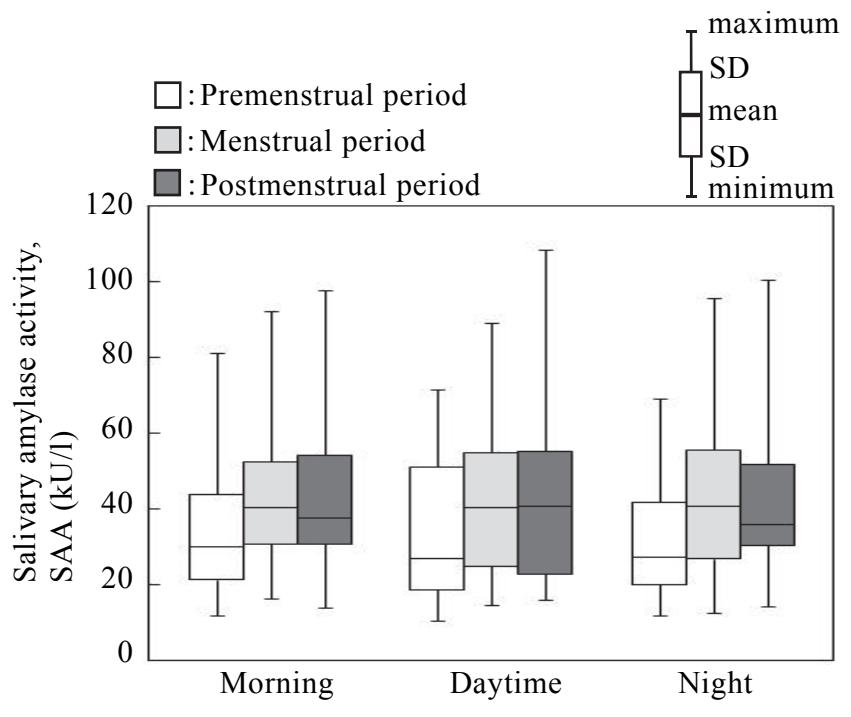

Fig.1 Time-course change of SAA. 


\section{2 唾液プロゲステロン}

全被検者の唾液プロゲステロン濃度は, 4.8 - $1393.8 \mathrm{pM}$ $(=1.5-438.3 \mathrm{pg} / \mathrm{ml})$ の範囲に分布した. 月経前, 月経 中, 月経後の唾液プロゲステロン濃度は, それぞれ $504.0 \pm$ 296.7, $207.7 \pm 138.3$, $227.1 \pm 147.9$ pM であった (Fig.2). Wilcoxon の符号順位和検定を行った結果，月経 前のプロゲステロン濃度は, 月経中, 月経後に対して有意に 高值を示し, 月経周期に伴う典型的な特徵が確認された (月経中，月経後ともに $d f=27, P<0.05$ ).

\section{3 主観評価}

全被検者の月経随伴症状に関する主観評価 MDQ の得点 は, $1-66$ 点に分布した. 月経前, 月経中, 月経後の MDQ は,それぞれ $29.1 \pm 18.5,32.3 \pm 16.3,15.7 \pm$ 12.6 であった（Fig.3). Wilcoxon の符号順位和検定を行 った結果, 月経前と月経中の MDQ が, 月経後に対して有意 に高值を示した（月経前と月経中, ともに $d f=27, P<$ $0.05)$.

3.4 唾液アミラーゼ活性, 唾液プロゲステロン濃度, $M D Q の$ 相関関係

唾液アミラーゼ活性と唾液プロゲステロン濃度に関しては, 月経中の唾液プロゲステロン濃度に対する月経中の朝およ び月経後の昼の唾液アミラーゼ活性の相関係数において, と もに一 0.4 が観察され, 緩やかな負の相関があると考えられた (Table 1). それ以外の項目には有意な相関は観測されなか った.

唾液アミラーゼ活性と MDQ に関しては, いずれの条件に おいても, 統計的に有意な相関は観測されなかった.

唾液プロゲステロン濃度と MDQ に関しては, 月経後の唾 液プロゲステロン濃度に対する月経前および月経中の MDQ の相関係数において, ともに 0.4 が観察され, 緩やかな正の 相関があると考えられた. それ以外の時間には, 有意な相関 は観測されなかった。

\section{5 唾液アミラーゼ活性の変化量と唾液プロゲステロン}

\section{濃度, MDQの関係}

月経前, 月経中の唾液アミラーゼ活性から, 月経後の唾液 アミラーゼ活性を引くことでその差分を求め(唾液アミラ 一ゼ活性の変化量; $\Delta \mathrm{SAA})$, 唾液プロゲステロン濃度と MDQ に対する相関係数を求めたところ, Table 2 の結果が 得られた.

唾液アミラーゼ活性の変化量と唾液プロゲステロン濃度に 関しては, 月経中の朝の $\Delta \mathrm{SAA}$ に対する月経中及び月経後 の唾液プロゲステロン濃度の相関係数において, ともに一 0.4 が観察され, 緩やかな負の相関があると考えられた. それ以 外の時間には, 有意な相関は観測されなかった.

唾液アミラーゼ活性の変化量と MDQ に関しては, 月経前 の夜の $\Delta \mathrm{SAA}$ と月経前, 月経中, 月経後の $\mathrm{MDQ}$ の相関係 数はそれぞれ $0.7,0.5,0.5$ となり, 有意な相関が観察された. それ以外の時間には, 有意な相関は観測されなかった。

\section{4. 考察}

唾液プロゲステロン濃度は, 4.77 - $1393.8 \mathrm{pM}$ の範囲に 分布し,これは $100 \mathrm{pM}$ 以下から $1500 \mathrm{pM}$ に分布すると 報告した先行研究と大差なかった ${ }^{9)-11)}$.

月経随伴症状には, 月経前に症状が現れる月経前症候 群と, 月経中に症状が現れる月経困難症がある. Fig.3 にお いて, 月経前と月経中の $\mathrm{MDQ}$ が，月経後よりも有意に高い 結果となったのは, 本被検者がこれらの月経随伴症状による 身体的, 精神的不調・変調を自覚していたことを示している. また, 月経前と月経中の MDQ は, 月経後のプロゲステロン 濃度と緩やかな相関があることが示され, 月経随伴症状の影 響が少ないほど, プロゲステロン濃度が低くなることが示唆さ れた。

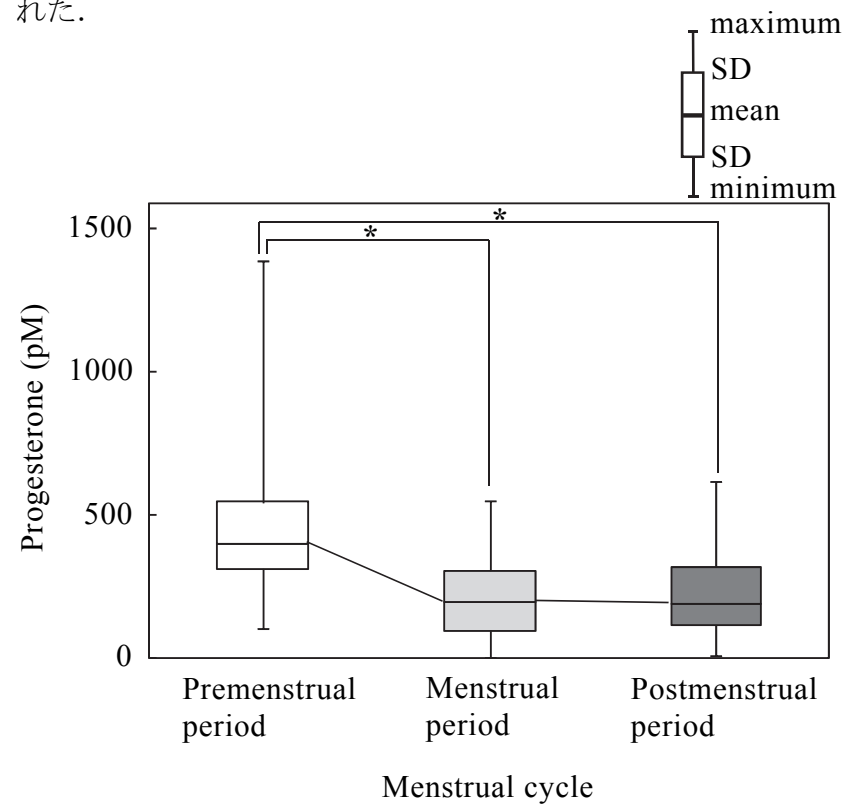

Fig.2 Time-course change of progesterone concentration $(*: P<0.05)$.

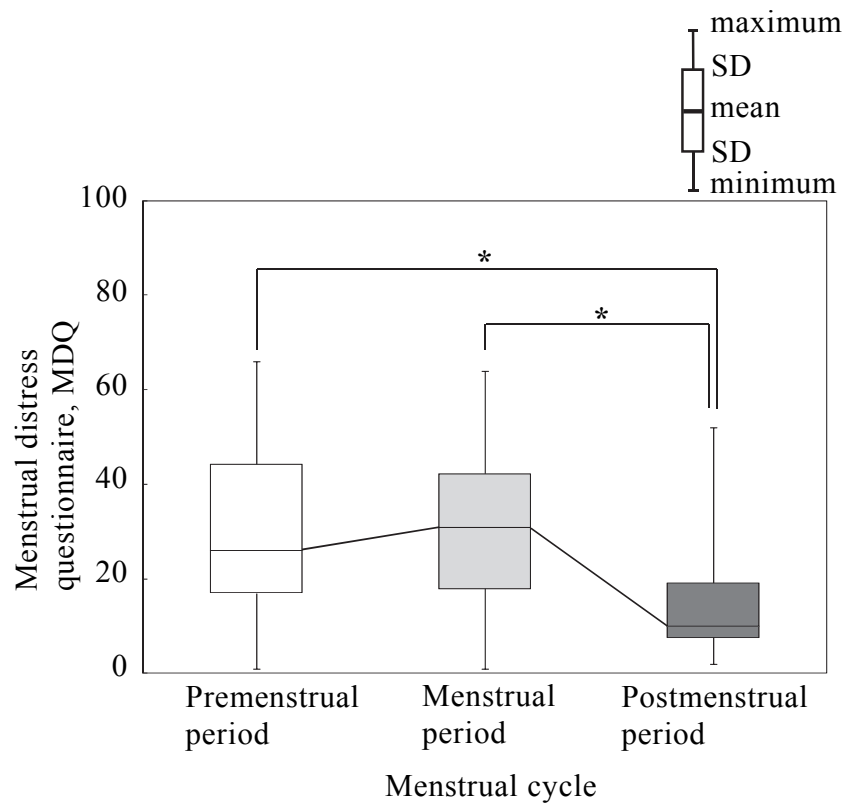

Fig.3 Time-course change of MDQ (*: $P<0.05)$. 
Table 1 Correlation of SAA, Progesterone, and MDQ (*: $P<0.05)$.

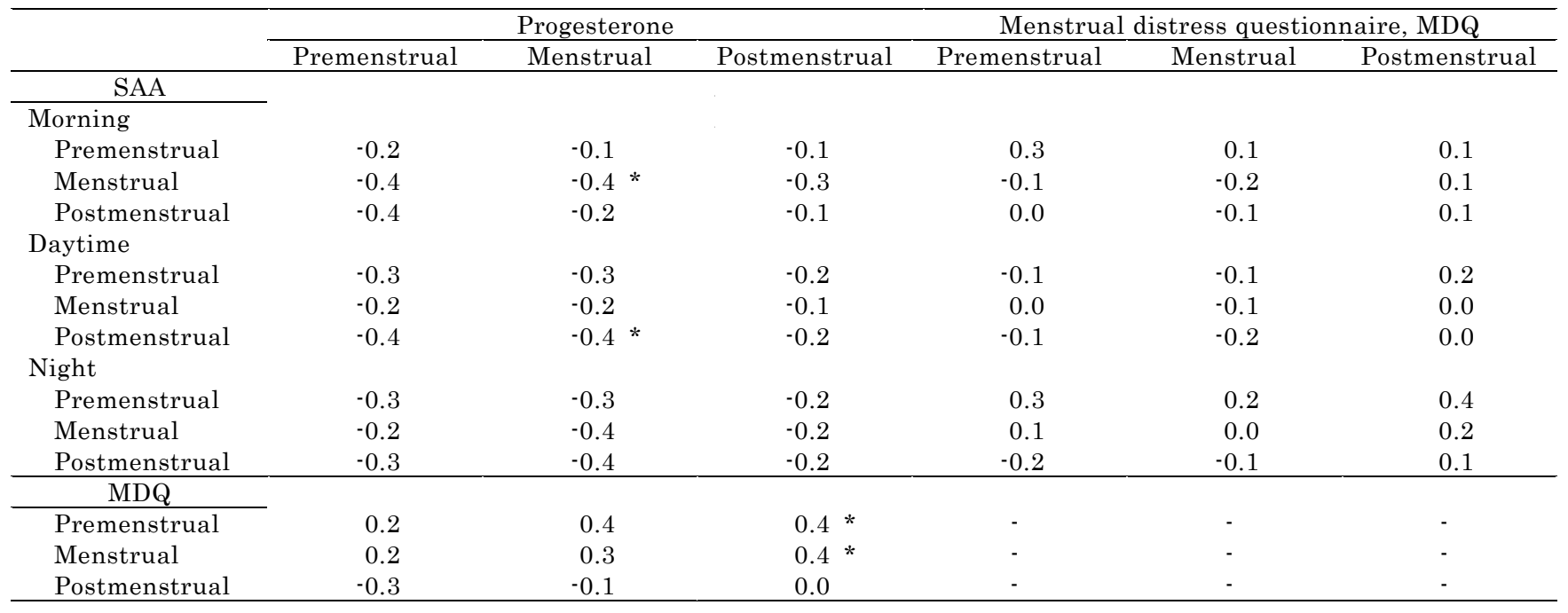

Table 2 Correlation between SAA variation $(\triangle \mathrm{SAA})$ and Progesterone, MDQ $(*: P<0.05)$. $\triangle$ SAA showed the subtracted value of SAA during postmenstrual period from the SAA during premenstrual or menstrual periods.

\begin{tabular}{|c|c|c|c|c|c|c|}
\hline \multirow{2}{*}{$\Delta \mathrm{SAA}$} & \multicolumn{3}{|c|}{ Progesterone } & \multicolumn{3}{|c|}{ Menstrual distress questionnaire, MDQ } \\
\hline & Premenstrual & Menstrual & Postmenstrual & Premenstrual & Menstrual & Postmenstrual \\
\hline \multicolumn{7}{|l|}{ Morning } \\
\hline Premenstrual & 0.2 & 0.1 & -0.0 & 0.3 & 0.1 & 0.0 \\
\hline Menstrual & -0.1 & $-0.4 *$ & $-0.4 *$ & -0.1 & -0.2 & 0.0 \\
\hline Postmenstrual & - & - & - & - & - & - \\
\hline \multicolumn{7}{|l|}{ Daytime } \\
\hline Premenstrual & 0.1 & 0.1 & 0.1 & 0.0 & 0.1 & 0.2 \\
\hline Postmenstrual & - & - & - & - & - & - \\
\hline \multicolumn{7}{|l|}{ Night } \\
\hline Premenstrual & 0.1 & 0.0 & 0.1 & $0.7 *$ & $0.5 *$ & $0.5 *$ \\
\hline Menstrual & 0.2 & -0.1 & 0.0 & 0.3 & 0.2 & 0.1 \\
\hline Postmenstrual & - & - & - & - & - & - \\
\hline
\end{tabular}

一方, 交感神経活性を反映し, 心身ストレスのマーカーとして 広く利用されている唾液アミラーゼ活性は, 月経周期による 有意な経時変化はみられず, 月経前および月経中の MDQ との間にも, いかなる相関も観察されなかった（Fig.3, Table 1).ただし, MDQ の值が有意に小さくなる月経後の唾液アミ ラーゼ活性を基準しして, 月経前, 月経中の変化量 $\Delta \mathrm{SAA}$ を 計算したところ, 月経前の夜の $\Delta \mathrm{SAA}$ が大きくなるほど，月 経前, 月経中, 月経後の MDQ が有意に増加することが示さ れ (Table 2), 唾液アミラーゼ活性の分析によって, 月経随 伴症状の程度を推測できる可能性が示唆された。

\section{5. 結言}

本研究では, 月経周期に伴う心身ストレスを, 唾液バイオ マーカーで定量評価できるか否かを検証するために, 交感神 経活性の指標であるアミラーゼ活性と, 女性ホルモンの指標 であるプロゲステロン濃度の経時変化を同時に分析し, 月経 随伴症状の主観評価 $\mathrm{MDQ}$ との比較を行った. その結果, 月 経前, 月経中の MDQ が大きいほど, 月経後のプロゲステロ
ン濃度が高くなる傾向が示された. また, 唾液アミラーゼ活性 の変化量が大きくなるほど, 月経前, 月経中, 月経後の $\mathrm{MDQ}$ が有意に増加し, 唾液アミラーゼ活性から月経随伴症 状の程度を推測できる可能性が示唆された。

\section{謝 辞}

データ収集に協力されたユニ・チャーム侏の宮澤 清氏， 谷 文美氏, 小西礼子氏に謝意を表する. 本研究の一部は, 平成 $22-24$ 年度 文部科学省科学研究費補助金 基盤研 究(C)（課題番号:22500400）「ホルモン分析のための流体 制御を利用した非侵襲イムノセンサの開発」（研究代表者: 山口昌樹）によって行われた.

\section{参考文献}

1) Frank R.T. The hormonal causes of premenstrual tension, Archives of Neurological Psychiatry 1931; 26: 1053-1057.

2) Greene R., Dalton K. The premenstrual 
syndrome, British Medical Journal 1953; 1: 1007.

3) Dalton K. The premenstrual syndrome. London: Heinemann, 1964.

4) Moos R.H., The development of a Menstrual Distress Questionnaire, Psychosomatic Medicine 1968; 30: 853-867.

5) Hawes E., Oei T.P.S., The menstrual distress questionnaire: are the critics right?, Current Psychology 1992; 264-281.

6）秋山昭代, 茅島 江子, MDT (Mirror Drawing Test）からみた性周期の心身に及ぼす影響について, 四大学看護学研究会雑誌 1979; 1(2): 61-66.

7) Yamaguchi M., Kanemori T., Kanemaru M., Takai N., Mizuno Y., Yoshida H., Performance evaluation of salivary amylase activity monitor, Biosens Bioelectron 2004; 20: 491-497.

8) Yamaguchi M., Deguchi M., Wakasugi J., Ono S., Takai N., Higashi T., Mizuno Y., Hand-held monitor of sympathetic nervous system using salivary amylase activity and its validation by driver fatigue assessment, Biosens Bioelectron 2006; 21: 1007-1014.

9) Vining RF, McGinley RA., Hormones in saliva, Crit Rev Clin Lab Sci. 1986; 23: 95-146.

10) Gombe S., Salivary and plasma progesterone and oestrogen during the menstrual cycle and pregnancy, East Afr Med J. 1977; 54: 476-479.

11) Connor ML, Sanford LM, Howland BE., Saliva progesterone throughout the menstrual cycle and late pregnancy, Can J Physiol Pharmacol 1982; 60: 410-413. 